\title{
Pengaruh Atonik Terhadap Pertumbuhan Dan Produksi Tomat (Solanum lycopersicum L.) Varietas Servo
}

\section{The Effect of Atonic on Growth and Production of Tomatoes (Solanum lycopersicum L.) Variety Servo}

\author{
Feby Noor Budi M. W. A. K ${ }^{1}$ Hamidah $^{2}$, Suroto ${ }^{2}$ \\ 1 Alumni Program Studi Agroteknologi, Fakultas Pertanian, Universitas Widya Gama Mahakam Jl. KH. Wahid \\ Hasyim, Sempaja, Samarinda, Kalimantan Timur, Indonesia \\ 2 Tenaga Pendidik Program Studi Agroteknologi, Fakultas Pertanian, Universitas Widya Gama Mahakam Jl. \\ KH. Wahid Hasyim, Sempaja, Samarinda, Kalimantan Timur, Indonesia
}

Diterima : 3 September 2019 Disetujui : 31 Desember 2019

Email : FebyNBudi@gmail.com, hamidah@uwgm.ac.id, surotohs.65@gmail.com

\begin{abstract}
Atonic Effect on Growth and Production of Servo Varietal Tomatoes. The purpose of this study was to obtain the best atonic concentration on the growth and production of servo tomato varieties. This research was conducted for 5 months, starting from January to June 2018, starting from land preparation, planting, maintenance, harvesting to data collection. This research was conducted at Bumi Sempaja Blok A Housing, Sempaja Selatan Village, North Samarinda District. The study was arranged in a 5x1 Randomized Block Design and repeated 5 times. With treatment p0 (control), p1 (1 cc), p2 (2 cc), p3 (3cc) and p4 (4cc). The results of this study indicate that the atonic treatment has a very significant effect on the treatment of plant height, the number of flowers, the length of fruit to ripen, the number of fruits and production, but does not affect the duration of flower buds into fruit.
\end{abstract}

Keywords: Atonic, Growth and Production of Tomatoes

\section{PENDAHULUAN}

Peningkatan produksi pangan pada umumnya dan hasil sayuran pada khususnya, dimaksudkan sebagai salah satu usaha untuk meningkatkan tarap hidup petani yang di arahkan pada nilai gizi masyarakat.

Salah satu jenis sayuran yang merupakan sumber mineral dan vitamin terutama kalsium, zat besi terutama kation, di samping itu memiliki nilai ekonomis yang tinggi serta merupakan tanaman agroindustri adalah tomat dengan nama ilmiah Solanum lycopersicum L. Di Indonesia tanaman tomat kebanyakan di tanam di daerah dataran tinggi, namun demikian tidak berarti tanaman tomat tidak dapat di tanam pada daerah dataran rendah (Hendra. 2014 ).

Tanaman tomat (Solanum lycopersicum L) di daerah Kalimantan Timur menurut Badan Pusat Statistik pada tahun 2011- 2015 sudah mengalami perluasan penanamannya dan hasil yang di dapat sudah mengalami peningkatan dibeberapa tahun belakangan ini yaitu dengan tertinggi hasilnya terjadi pada tahun 2014 sekitar 12,347 ton/ha, sedangankan pada tahun 2015 mengalami penurunan yang siknifikan dan hasil panen hanya sekitar 8,048 ton/ha. Namun belum mencukupi kebutuhan tomat di Kalimantan Timur jadi untuk mencukupi kebutuhan komoditi ini daerah Kalimantan Timur masih mendatangkan dari jawa timur serta daerah penghasil tomat lainnya (BPS Kalimantan Timur, 2015).

Sebenarnya hal ini masih dapat ditingkatkan, salah satunya melalui "Intensifikasi Pertanian" yang dapat diartikan sebagai usaha peningkatan serta penggiatan pemanfaatan berbagai macam sarana produksi pertanian secara ekonomis pada suatu luasan tanah tertentu yang meliputi penggunaan varietas unggul, pengolahan tanah, penetapan polah tanam, pemupukan serta pemberantasan hama penyakit . Salah satu ZPT yang banyak beredar saat ini adalah Atonik, atonik adalah ZPT yang mengandung garam natrium senyawa fenol yang berwarna coklat yang dapat larut dalam air dan mempunyai aroma spesifik. Bahan utama komponen aktifnya terdiri dari natrium 5-nitroguaicol $\left(\mathrm{C}_{7} \mathrm{H}_{6} \mathrm{NO}_{4} \mathrm{Na}\right)$, natrium ortonitrofenol $\left(\mathrm{C}_{6} \mathrm{H}_{4} \mathrm{NO}_{3} \mathrm{Na}\right)$, natrium para-nitrofenol $\left(\mathrm{C}_{6} \mathrm{H}_{4} \mathrm{NO}_{3} \mathrm{Na}\right)$ dan natrium 2.4dinitrofenol $\left(\mathrm{C}_{6} \mathrm{H}_{3} \mathrm{~N}_{2} \mathrm{O}_{5} \mathrm{Na}\right)$. Adapun pengaruhnya terhadap pertumbuhan dan perkembangan tanaman adalah mempercepat aliran protoplasma 
dan pertumbuhan perakaran, merangsang pembungaan, pertunasan, memecahkan dormansi, mencegah gugur bunga dan buah, merangsang perkembangan serbuk sari, memperpanjang tabung serbuk sari, mendorong fertilisasi dan pembuahan serta memperbaiki kualitas buah. Wibowo (2011), mengatakan bahwa perendaman biji buah-buahan dalam larutan Atonik $0,5 \mathrm{~mL} \mathrm{~L}^{-1}$ air selama 10 jam dapat mempercepat berkecambahnya biji.

Benhard S Vell dan Rolinse. (2013) bahwa pengaruh penggunaan zat tumbuh atau sejenis perangsang tanaman, ini sangat tergantung pada cara pemakaiannya. Jadi pengetahuan dasar tentang penggunaan hormone atau sejenis zat perangsang ini sangat di perlukan supaya pemakaian zat ini efektif dan ekonomis.

Menurut Utama dan Antara (2013), bahwa penggunaan zat tumbuh atau perangsang tumbuh di Negara yang sudah maju dan berkembang merupakan pekerjaan yang sudah rutin sebagai mana halnya dengan penggunanaan pupuk atau pestisida, dan ini merupakan titik tolak dalam meningkatkan mutu hasli pertanian pada

\section{HASIL DAN PEMBAHASAN}

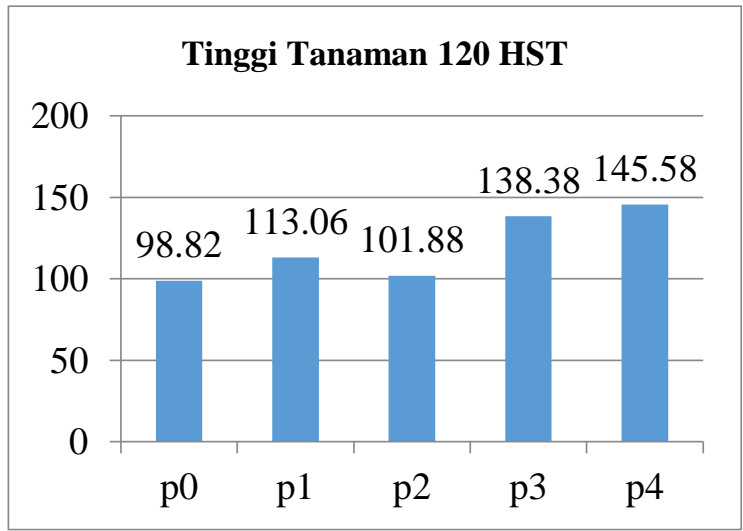

Gambar 1. Grafik hubungan atonik dengan tinggi tanaman

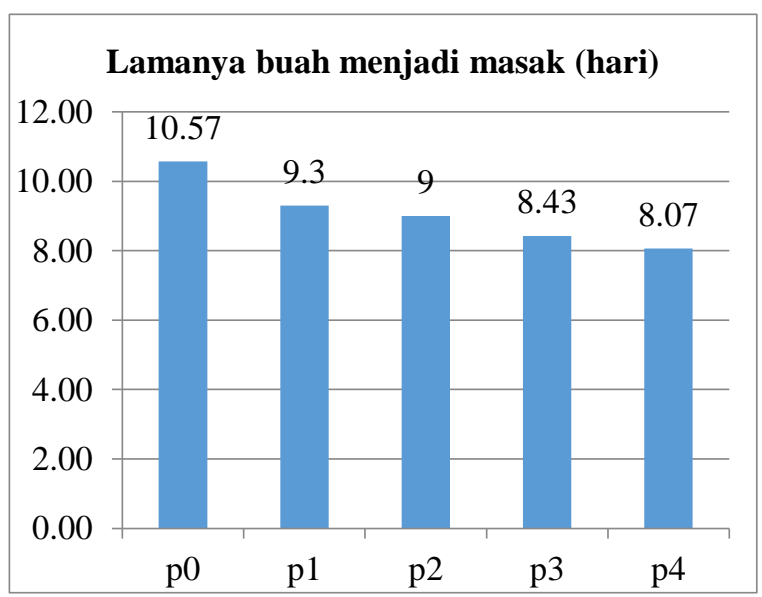

Gambar 3. Grafik hubungan atonik dengan lamanya buah menjadi masak umumnya dan khususnya komoditi - komoditi yang memiliki nilai ekonomis tinggi.

\section{BAHAN DAN METODE}

Bahan-bahan yang di gunakan : Benih tomat varietas Servo, pupuk kandang kambing, NPK, atonik. Penelitian ini dilakukan selama 5 bulan yakni dimulai pada bulan Januari-Juni 2018, terhitung mulai persiapan lahan, penanaman, pemeliharaan, pemanenan hingga pengambilan data. Penelitian ini disusun dalam Rancangan Acak Kelompok 5x1 dimana masing - masing taraf diulang sebanyak 5 kali. Adapun variasi konsentrasi atonik yg dilakukan adalah sebagai berikut : p0 $=$ kontrol (disemprot dengan air), p1 $=1 \mathrm{cc}$ atonik per liter air, $\mathrm{p} 2=2 \mathrm{cc}$ atonik per liter air, p3 $=3 \mathrm{cc}$ atonik per liter air dan p4 = 4 cc atonik per liter air. Analisis data dengan menggunakan sidik ragam RAK, apabila terdapat pengaruh pada sidik ragam maka dilakukan uji BNT 5\% untuk membandingkan rata-rata perlakuan.

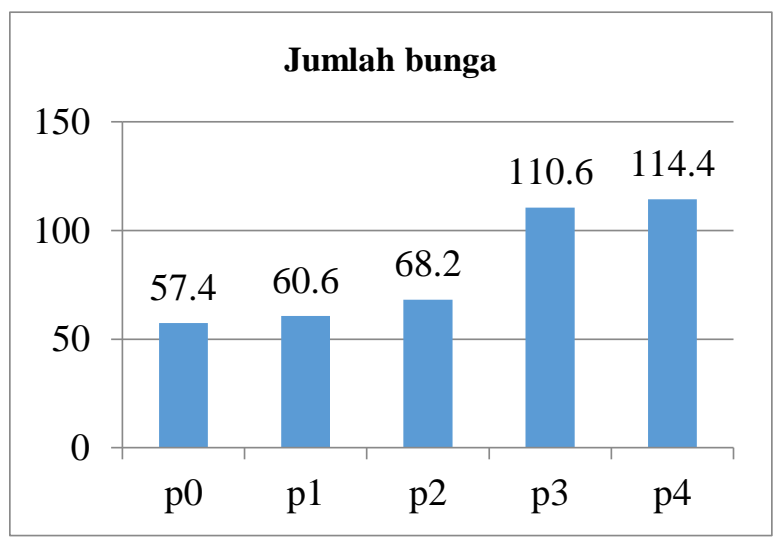

Gambar 2. Grafik hubungan atonik dengan jumlah bunga

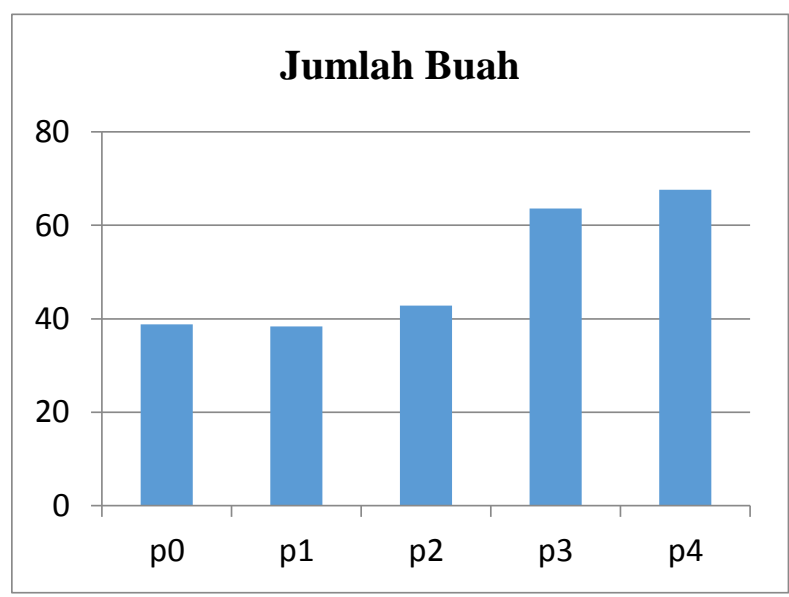

Gambar 4. Hubungan atonik terhadap jumlah buah 
Hasil sidik ragam menunjukan bahwa pengaruh ZPT Atonik sangat nyata terhadap tinggi tanaman umur 120 HST. Tinggi tanaman terbaik di tunjukan oleh perlakuan p4 dengan rataan $145,58 \mathrm{~cm}$ sedangkan yang terendah di tunjukan oleh perlakuan p0 dengan rataan 98,82 $\mathrm{cm}$ pada gambar 1 . Keadaan ini menunjukkan bahwa pemberian ZPT Atonik dapat mendorong pertumbuhan vegetatif tanaman seperti tinggi tanaman. Seperti dinyatakan oleh (Saputra J. 2014) bahwa ZPT Atonik secara biokimia aktif merangsang seluruh jaringan tanaman dan langsung meresap melalui akar, batang dan daun. Selanjutnya (Saputra J. 2014) bahwa manfaat dari ZPT Atonik adalah mendorong pertumbuhan akar tanaman, sehingga tanaman tumbuh subur dan cepat.

Hasil sidik ragam menunjukan bahwa perlakuan atonik menunjukan berpengaruh sangat nyata terhadap jumlah bunga hal ini di sebabkan oleh pemberian atonik dengan dosis yang tepat. rataan jumlah bunga tertinggi ada pada perlakuan p4 dengan rata-rata jumlah bunga 114,4, sedangkan rataan terendah ada pada perlakuan p0 dengan rataan 57,4. Pada gambar 2. Hal ini menurut (Fatimah, 2012), bahwa tanaman tomat yang menjelang berbunga membutuhkan karbohidrat yang relatif besar, serta zat-zat makanan yag mengandung nitrogen yang mana sangat berguna sekali dalam pembentukan serbuk sari. Disamping faktorfaktor ketersedian karbohidrat serta zat-zat pembentuk hormon yang aktif dalam proses pembentukan dan proses pembungaan, bahwa suhu pada malam hari sangat menentukan terjadinya pembuahan.

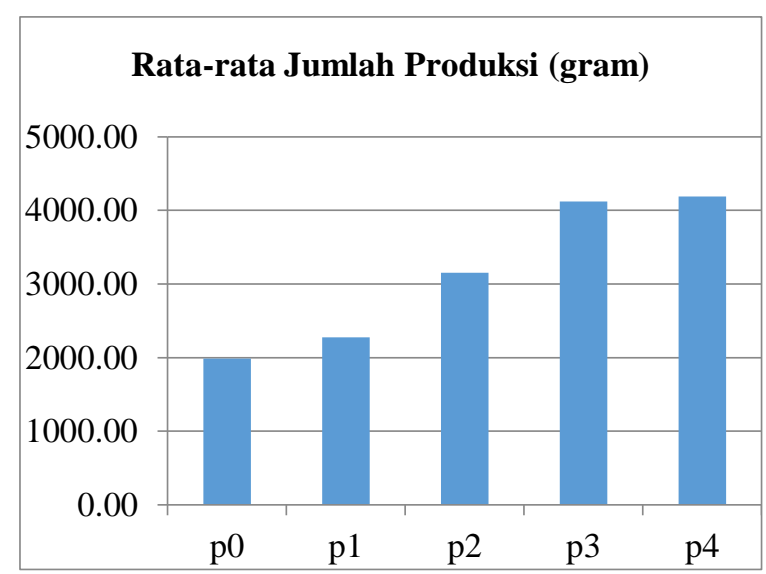

Gambar 5. Grafik hubungan atonik terhadap jumlah produksi

Disamping faktor-faktor ketersediaan karbohidrat serta zat-zat pembentuk hormon yang aktif dalam proses pembentukan dan proses pembungaan, bahwa suhu pada malam hari, sangat menentukan pembuahan. Menurut (Hernita, 2003), bahwa tanaman tomat tidak akan dapat membentuk bunga apabila mendapat suhu yang terlalu tinggi. Untuk pembentukan buah tanaman tomat memerlukan suhu $23^{\circ} \mathrm{C}$ pada waktu siang hari dan $17^{\circ} \mathrm{C}$ pada malam hari. Selisih yang ideal adalah $7^{\circ} \mathrm{C}-10{ }^{\circ} \mathrm{C}$. Sedangkan suhu siang hari tempat di laksanakan percobaan adalah antara $24^{\circ}-32^{\circ} \mathrm{C}$ dan suhu pada malam hari antara $23^{\circ} \mathrm{C}-26^{\circ} \mathrm{C}$

Hasil dari sidik ragam menunjukan pengaruh atonik terhadap lamanya kuncup bunga menjadi buah, tidak ada menunjukan perbedaan nyata, hanya ada kecendrungan dengan penambahan konsentrasi atonik hingga konsentrasi yang dicobakan dapat mempengaruhi percepatan umur kuncup menjadi buah. Keadaan ini sesuai dengan peranan atonik plant stimulans, dimana dapat meningkatkan pertumbuhan vegetatif dan generatif (Wibowo. S 2011), dan menurut Wibowo s (2011) mengatakan bahwa zat perangsang atau plant stimulans mendorong pembentukan bunga yang sudah ada di dalam tanaman di dorong untuk keluar.

Hasil sidik ragam menunjukan bahwa perlakuan atonik menunjukan berpengaruh sangat nyata terhadap lamanya buah menjadi masak serta terjadi percepatan waktu buah menjadi masak terhadap kontrol. Namun pada perlakuan atonik p4 dengan rataan 8,07 hari menunjukan kecendrungan waktu pematangan buah lebih cepat, sedangkan yang terendah ada pada perlakuan p0 dengan rataan 10,57 hari. Lamanya buah menjadi masak di tunjukan pada gambar 3. Hal ini sesuai dengan pendapat Menurut (Dani saputra, 2012) ZPT dapat memperbaiki sistem perakaran, mempercepat keluarnya akar bagi tanaman muda (bibit), memperkaya pertumbuhan vegetatif dan anakan, mencegah gugur daun, bunga dan anakan serta mempercepat pematangan buah dengan warna yang seragam dan hasil tinggi.

Hasil sidik ragam perlakuan atonik terhadap kelompok menunjukan tidak berpengaruh nyata pada kelompok, namun berpengaruh nyata pada perlakuan, hal ini di sebabkan pemberian dosis atonik yang tepat pada tanaman, dengan rataan jumlah buah tertinggi pada perlakuan p4 dengan jumlah rataan 67,6 buah dan yang terendah ada pada perlakuan p1 dengan rataan 38,4 buah. Seperti yag terlihat pada grafik. Pengaruh atonik terhadap jumlah buah di tunjukan pada gambar 4. Ini sesuai dengan pendapat (Herniati, 2010), apabila tanaman dalam masa permulaan tumbuhnya mempunyai laju fotosintesis yang cepat didukung dengan faktor-faktornya, maka sejumlah karbohidrat terbentuk dan bersenyawa 
dengan persenyawaan nitrogen dan terbentuk protoplasma, maka disini trjadi proses vegetatif dominan terhadap proses generatif dimana hasilnya akan rendah. Terlihat pada tabel 2 dan tabel 5 bahwa, jumlah bunga dan buah menunjukan perbedaan yang nyata dan mempunyai hubungan grafik yang linear terhadap perlakuan atonik, akan tetapi mempunyai hasil buah yang rendah.

Hasil sidik ragam menunjukan atonik berpengaruh sangat nyata terhadap jumlah produksi. Setelah di uji dengan BNT 5\% pada perlakuan p4 menunjukan beda yang sangat nyata pada kontrol, dimana pada konsentrasi atonik p4 memiliki hasil rataan 4186,28 g berbeda jauh dengan kontrol yang hanya memiliki hasil rataan 1987,04 g. Sebagaimana kita ketahui bahwa pembentukan karbohidrat merupakan faktor yang sangat mendasar untuk mencapai produksi yang maksimum, dalam pemanfaatan karbohidrat untuk pertumbuhan vegetatif dan generatif apabila keadaan ini seimbang maka produksi akan tinggi, Pengaruh atonik terhadap jumlah produksi (gram) di tunjukan oleh gambar 5.Menurut (Harjadi,

\section{KESIMPULAN}

1. Perlakuan atonik hingga konsentrasi yang di uji coba $(4 \mathrm{cc})$ dapat mempengaruhi tinggi tanaman, jumlah bunga dan jumlah buah secara nyata.

2. Perlakuan atonik sangat mempengaruhi produksi tomat, pada konsentrasi atonik 4cc menunjukan rataan produksi tomat tertinggi yaitu 4186,28 gram pertanaman.

\section{DAFTAR PUSTAKA}

Benhard S, Vell dan Rolinse. (2013). Dasar-dasar Teknologi Tanaman. Yasaguna, Jakarta.

BPS Kaltim, 2015. BPS.kaltim.com di akses pada 18 November 2017.

Dani saputra, 2012. Peranan Zat Pengatur Tumbuh (ZPT) dalam Pertumbuhan dan perkembangan Tumbuhan.

Didit. 2010. Cara Budidaya Tomat (Lycopersicon esculentum Mill). Poltikes Press.Surakarta.

Ekawidiasta, 2014. Klasifikasi tanaman tomat. B. Gramedia, Jakarta.
2009), bahwa produksi maksimum merupakan akibat dari serentetan peristiwa biokimia yang meliputi pengisapan dan pergerakan air dan zatzat hara, penyusun dan pembongkar protein dan lemak bagian tanaman. Setelah tanaman mengurangi fase vegetatif maka taranslokasi makanan dialihkan kepada fase generatif. Pengaruh perlakuan atonik terhadap rata-rata produksi tomat menunjukan perbedaan yang sangat nyata hal ini sesuai dengan peranan dan kegunaan atonik bahwa atonik dapat bekerja secara biokimia dan mempengaruhi aliran plasma di dalam sel, serta atonik ini dapat meningkatkan penyerapan terhadap unsur hara, traslokasi zat-zat makanan serta proses fisiologis dalam tanaman. Fase generatif ini di awali dengan pembentukan serbuk sari yang berfungsi sebagai zat yang membuahi, juga serbuk sari ini mengandung hormon yang sama dengan auksin yaitu thianin (pada tanaman tomat), tetapi bnayaknya tidak cukup untuk perkembagan buah. Pertumbuhan dan perkembagan buah di stimulir oleh auksin yang ada dalam indospera, yang mana berasal dari persatuan dua sel telur dengan satu sel jantan didalam kantong embrio.

Fatimah, 2012. Pengaruh Rooton F dan Atonik Terhadap Pertumbuhan Tomat Tombatu Pada Beberapa Media Tanaman.

Harjadi, Sri. Setyati. 2009. Zat Pengatur Tumbuh. Penebar Swadaya. Jakarta.

Hendra, 2014 . Tomat Budidaya dan Analisis Usaha Tani. Kanisius, Yogyakarta.

Hernita, D. 2003. Teknologi Perbanyakan Tanaman Buah Unggulan Jambi. Prosiding Seminar Nasional Hasil-Hasil Penelitian Pengkajian Teknologi Spesifik Lokasi, tanggal 23 - 24 November 2005 di BPTP Jambi. Balai Pengkajian Teknologi Pertanian, Jambi.

Herniati, 2010. Pengaruh Pemberian Zat Pengatur Tumbuh terhadap Hasil, Kualitas dan Umur Simpan Buah Tomat Kultivar Gondol.

http://rajalia.blogspot.com/2012/12/perananzat-pengatur-tumbuh-zpt-dalam.html 01/07/2018: 15:20

Maliakus, 2014. Kesuburan tanah pertanian dan usaha merahabilitasinya. Bina Aksara, Jakarta. 
Redaksi Agromedia, 2013. Panduan Lengkap Budi Daya Tomat. Agromedia.

Rivai, F., 2005. Dasar-Dasar Epidemiologi Penyakit Tumbuhan. Yayasan Perguruan Tinggi Komputer UPI PRESS. Padang.

Saputra, J., 2014. Pengaruh Pemberian Pupuk Suburin dan ZPT Atonik Terhadap Pertumbuhan dan Produksi Kacang Hijau. JGS Vol.1 No. 1 Hal:25-32

Sampul pertanian, 2017 www.sampulpertanian.com di akses pada 20 januari 2018

Saragih, W.C. 2008. Respon Pertumbuhan dan Produksi Tomat Terhada Pemberian Pupuk Phospat dan Bahan Organik. Skripsi. Universitas Sumatera Utara.
Utama, I M. S. dan N. S. Antara. 2013. Pasca Panen Tanaman : Buah Dan Sayur.

Wiryanta,W.T.B, 2011. Bertanam Tomat. Agromedia Pustaka, Jakarta.

Wartapa, A., dan Sukadi. 2009. Pengaturan jumlah cabang utama dan penjarangan buah terhadap hasil dan mutu buah tomat varietas kaliurang . Jurnal Ilmu-ilmu Pertanian Vol. 5 No. 2 150-162.

Project Udayana University.Jurnal Kultivasi Vol. 15(1) Maret 2016.

Wibowo, S. (2011). Pengaruh Penggunaan Stimulant Terhadap Pertumbuhan dan Hasil Tanaman Tomat (( Lycoperiscum esculentum Mill.). Jurnal Vol. 2 No. 1. Fakultas Pertanian Universitas Andalas, Padang.

Y. Efendi, 2011) Bertanam Tomat. Penebar Swadaya, Jakarta. 